\title{
Anti-Inflammatory Cycloartane-Type Saponins of Astragalus membranaceus
}

\author{
Dae-Young Lee ${ }^{1}$, Hyung-Jun Noh ${ }^{1}$, Jehun Choi ${ }^{1}$, Kyeong-Hee Lee ${ }^{1}$, Min-Ho Lee ${ }^{2}$, \\ Ji-Hyun Lee ${ }^{1}$, Yoonpyo Hong ${ }^{1}$, Seung-Eun Lee ${ }^{1}$, Seung-Yu Kim ${ }^{1}$ and Geum-Soog Kim ${ }^{1, *}$ \\ 1 Department of Herbal Crop Research, National Institute of Horticultural and Herbal Science, RDA, \\ Eumseong 369-873, Korea \\ 2 Department of Food Technology and Services, Eulji University, Seongnam 461-723, Korea \\ * Author to whom correspondence should be addressed; E-Mail: kimgs0725@korea.kr; \\ Tel.: +82-43-871-5582; Fax: +82-43-871-5589.
}

Received: 1 February 2013; in revised form: 19 March 2013 / Accepted: 20 March 2013 / Published: 25 March 2013

\begin{abstract}
A new cycloartane-type triterpene glycoside, agroastragaloside V (1) was isolated from the roots of Astragalus membranaceus. The structure was identified as 3-O$\beta$-(2'-O-acetyl)-D-xylopyranosyl-6- $O$ - $\beta$-D-glucopyranosyl-(24S)-3 $\beta, 6 \alpha, 24 \alpha, 25$-tetrahydroxy9,19-cyclolanostane, by means of spectroscopic methods, including HR-FAB/MS, 1D NMR $\left({ }^{1} \mathrm{H},{ }^{13} \mathrm{C}\right.$, DEPT), 2D NMR (gCOSY, gHSQC, gHMBC, NOESY), and IR spectroscopy. Four known cycloartane glycosides, namely, agroastragaloside I (2), agroastragaloside II (3), isoastragaloside II (4) and astragaloside IV (5) were also isolated. All isolated compounds were tested for the ability to inhibit LPS-induced nitric oxide production in RAW264.7 macrophages.
\end{abstract}

Keywords: Astragalus membranaceus; cycloartane-type triterpene; agroastragaloside V; nitric oxide

\section{Introduction}

Astragalus species are among the most widely distributed in northern temperate regions and tropical African mountains [1]. Five species have been identified in Korea and the primary parts used for medicinal purposes, are cylindrical, but not usually branched, measure around 30-90 cm in length, and are covered with a tough, yellowish-brown skin with a sweet white inner pulp [2]. Radix astragali, 
the dried root of Astragalus membranaceus (FISCH.) BGE., known as Huangqi in China and Korea, is one of the most widely used medicinal herbs prescribed in many Chinese formulas to reinforce "Qi" (the vital energy) [3]. Studies of its pharmacological and clinical uses have demonstrated that Astragali Radix has many biological functions, including hepatoprotection [4], neuroprotection [5], cardiotonic [6], anti-aging activity [7], anti-cancer effects [8], and anti-inflammatory effects [9]. Astragalus species are rich in cycloartane-type triterpene glycosides that possess diverse biological activities. Some cycloartane triterpene glycosides have been shown to have antitumor activity [10]. Astragaloside IV, a cycloartane triterpene glycoside extracted from Radix Astragali, has a broad range of pharmacological properties, including antiapoptotic [11], anti-inflammatory and antihypertensive [12] effects.

As part of our efforts to isolate the chemical constituents of Astragali Radix to evaluate A. membranaceus qualitatively, we report herein on the isolation of a new minor saponin, agroastragaloside V (1), obtained from the roots of $A$. membranaceus cultivated in Korea, together with four known compounds $\mathbf{2 - 5}$, and the structural determination of these substances using extensive spectroscopic methods. Several previous studies have provided immune stimulant effects of several cycloartane-type triterpene glycosides and the extracts on macrophage activation and expression of inflammatory cytokines were investigated from Astragalus species [9,12]. Therefore, isolated compounds 1-5 were evaluated for anti-inflammatory activities through the measurement of nitrite, a soluble oxidation product of nitric oxide (NO), in lipopolysaccharide (LPS)-induced RAW 254.7 macrophage cells.

\section{Results and Discussion}

A $80 \%$ methanolic extract of dried roots of $A$. membranaceus was suspended in $\mathrm{H}_{2} \mathrm{O}$ and extracted with EtOAc, and then $n$-BuOH. The EtOAc soluble fraction was concentrated under reduced pressure to produce a residue which was then subjected to multiple chromatographic steps using silica gel, reversed-phase C18, and Sephadex LH-20, yielding the compounds 1-5 (Figure 1).

Figure 1. Chemical structures of isolated compounds 1-5.

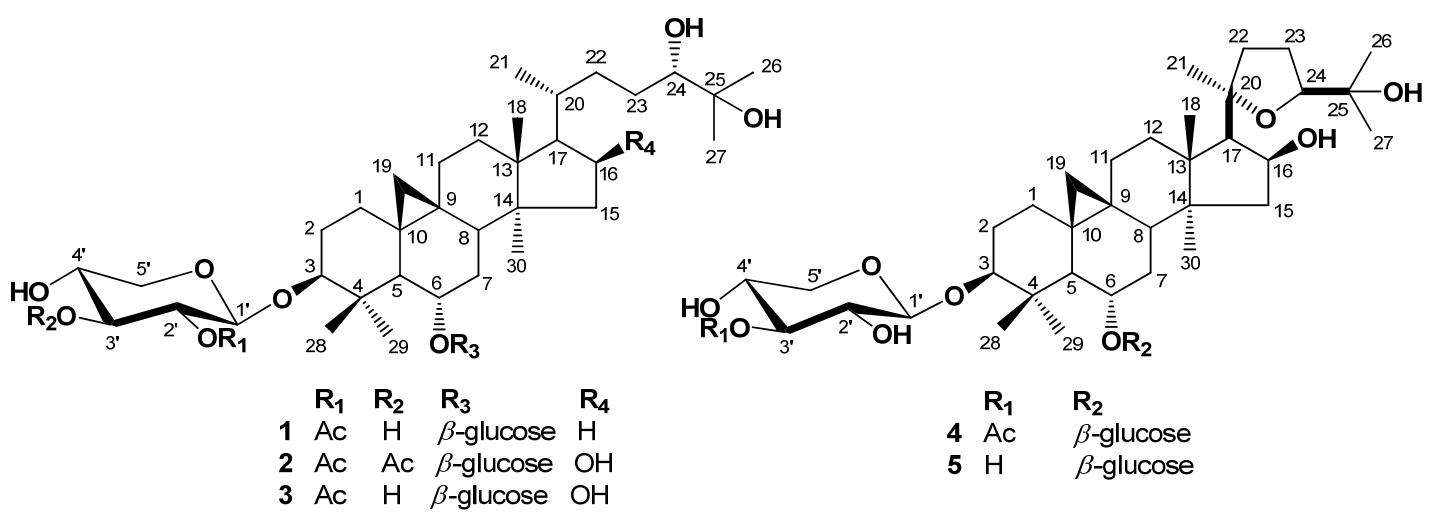

Compound 1, was obtained as an amorphous white powder from $\mathrm{MeOH}$. High-resolution (HR) FAB-MS exhibited an ion peak for $[\mathrm{M}-\mathrm{H}]^{-}$at $m / z$ 811.4777, which is compatible with the molecular formula $\mathrm{C}_{43} \mathrm{H}_{72} \mathrm{O}_{14}$. The IR spectrum of 1 showed the presence of a hydroxyl group $\left(3433 \mathrm{~cm}^{-1}\right)$ and an ester carbonyl group $\left(1,724 \mathrm{~cm}^{-1}\right)$. The ${ }^{1} \mathrm{H}-\mathrm{NMR}$ spectrum of $\mathbf{1}$ (Table 1) revealed the presence of a cyclopropane methylene group with signals at $\delta_{\mathrm{H}} 0.17(1 \mathrm{H}, \mathrm{d}, J=4.0 \mathrm{~Hz})$ and $0.53(1 \mathrm{H}, \mathrm{d}, J=4.0 \mathrm{~Hz})$ 
and also contained signals for six tertiary methyl groups at $\delta_{\mathrm{H}} 0.95,1.28,1.38,1.41,1.43$, and 1.78, and for one acetyl methyl group $\left(\delta_{\mathrm{H}} 2.03\right)$ which were correlated in HSQC with carbon signals at $\delta_{\mathrm{C}}$ $19.9,16.6,18.6,25.7,26.5,28.3$ and acetyl $\left(\delta_{\mathrm{C}} 21.2\right)$, respectively. A secondary methyl group at $\delta_{\mathrm{H}}$ $1.07(3 \mathrm{H}, \mathrm{d}, J=6.4 \mathrm{~Hz})$ and at $\delta_{\mathrm{C}} 18.3$, and four oxygen bearing methine proton signals at $\delta_{\mathrm{H}} 4.48$ (ddd, $J=8.0,8.0,5.2 \mathrm{~Hz}), 3.53(\mathrm{ddd}, J=9.5,9.5,4.5 \mathrm{~Hz}), 3.41(\mathrm{dd}, J=10.5,2.2 \mathrm{~Hz})$ and $3.23(\mathrm{dd}$, $J=11.3,4.0 \mathrm{~Hz}$ ), which were indicative of secondary alcoholic functions (Table 1), were readily noticed in the ${ }^{1} \mathrm{H}-\mathrm{NMR}$ spectrum. Furthermore, the ${ }^{1} \mathrm{H}-\mathrm{NMR}$ spectrum of $\mathbf{1}$ clearly showed two anomeric doublets at $\delta_{\mathrm{H}} 4.77(J=7.6 \mathrm{~Hz})$, and $4.96(J=7.2 \mathrm{~Hz})$ in the downfield region, indicating of the presence of two $\beta$-linked sugars. This was supported by the ${ }^{13} \mathrm{C}$-NMR spectrum, which showed two anomeric carbon signals at $\delta_{\mathrm{C}} 104.7$ and 105.2. The chemical shifts of the individual protons of the two sugar units were revealed from a combination of 2D-COSY spectral analyses, and ${ }^{13} \mathrm{C}$ chemical shifts of their relative attached carbons were assigned unambiguously from the HSQC and HMBC experiments which led to the identification of a $\beta$-xylopyranosyl unit and a $\beta$-glucopyranosyl unit. The sites of attachment of the xylose and glucose moieties of 1 were determined by HMBC experiment to be at C-3 and C-6, respectively. In the HMBC spectrum, the first anomeric proton signal at $\delta_{\mathrm{H}} 4.77$ (H-1') showed long range correlation with the carbon at $\delta_{\mathrm{C}} 89.0$ (C-3). Also the second anomeric proton signals at $\delta_{\mathrm{H}} 4.96$ ( $\left.\mathrm{H}-1 "\right)$ showed long-range correlation with the carbons at $\delta_{\mathrm{C}} 79.1$ (C-6), respectively. Consequently, xylose and glucose should be attached to the hydroxyl groups at C-3 and C-6. The relative configuration of OH-6 was confirmed by a NOESY experiment, which showed a correlation between H-6 and H-28, H-19a, as well as H-8. These NOE correlations indicated that the oxygen at $\mathrm{C}-6$ is $\alpha$-oriented. In the ${ }^{1} \mathrm{H}$-NMR spectrum, signals at $2.03(3 \mathrm{H}, \mathrm{s})$, and ${ }^{13} \mathrm{C}-\mathrm{NMR}$ signals at 170.0 , showed the presence of an acetoxyl group in $\mathbf{1}$. The NMR data of the acetoxyl moiety of $\mathbf{1}$ were in good agreement with those reported for agroastagaloside II (3) [13,14]. Also, the cross peak between the oxygenated methine proton signal of xylose $\left(\mathrm{H}-2^{\prime}\right)$ and the ester carbon signal $\left(\delta_{\mathrm{C}} 170.0\right)$ suggested that the acetyl group was linked to the hydroxyl of C-2' of xylose (Figure 2) in the HMBC spectrum. This was confirmed by the down-field shifts of the carbon $\left(\delta_{\mathrm{C}} 75.7\right)$ and proton signal $\left(\delta_{\mathrm{H}} 5.52, \mathrm{H}-2^{\prime}\right)$ owing to the esterification effect. The ${ }^{13} \mathrm{C}-\mathrm{NMR}$ spectrum of $\mathbf{I}$ displayed a total of 43 carbon signals. Based on a DEPT experiment, the HSQC spectrum, and a comparison with the ${ }^{13} \mathrm{C}$-NMR data of the related agroastagaloside II (3), all the signals could be assigned (Table 2). These data were similar to agroastagaloside II (3) with the exception of the proton and carbon resonances for the lack of an oxygenated methine moiety at the $\mathrm{C}-16$ position, respectively. The methylene signals due to $\mathrm{C}-16$ in $\mathbf{1}$ were replaced by those of an oxygenated methine $\left(\delta_{\mathrm{H}} 4.72\right.$ and $\left.\delta_{\mathrm{C}} 72.1\right)$ in agroastagaloside II (3) [14]. The molecular weight of $\mathbf{1}$ was $16 \mathrm{Da}$ less than that of agroastagaloside II (3), indicating the presence of one less hydroxyl group. This conclusion was also supported by the HMBC spectrum, which showed ${ }^{2} J,{ }^{3} J$, and long range correlation between the proton signal of $\mathrm{H}-17\left(\delta_{\mathrm{H}} 1.51\right)$ and the carbon signals of C-13 $\left(\delta_{\mathrm{C}} 45.8\right), \mathrm{C}-16\left(\delta_{\mathrm{C}} 28.7\right), \mathrm{C}-20\left(\delta_{\mathrm{C}} 28.6\right), \mathrm{C}-18\left(\delta_{\mathrm{C}} 18.6\right)$ and C-21 $\left(\delta_{\mathrm{C}} 18.3\right)$ (Figure 2$)$. The D-configurations of xylose and glucose units were established after hydrolysis of $\mathbf{1}$ followed by GC analysis [15]. Finally, the structure of $\mathbf{1}$ was determined to be $3-O-\beta$-(2'-O-acetyl)-Dxylopyranosyl-6- $O$ - $\beta$-D-glucopyranosyl-(24S)-3 $\beta, 6 \alpha, 24 \alpha, 25$-tetrahydroxy-9,19-cyclolanostane, and named agroastragaloside V. Comparisons of NMR and MS data for the known compounds 2-5 with reported values led to their identification as agroastragaloside I (2) [16], agroastragaloside II (3) [14], isoastragaloside II (4) [13] and astragaloside IV (5) [16], respectively (Figure 1). 
Table 1. ${ }^{1} \mathrm{H}-(400 \mathrm{MHz})$ and ${ }^{13} \mathrm{C}-\mathrm{NMR}(100 \mathrm{MHz})$ data of compound $\mathbf{1}$ (in pyridine- $d_{5}$, $\delta$ in ppm, $J$ in $\mathrm{Hz})^{\text {a }}$.

\begin{tabular}{|c|c|c|c|c|c|}
\hline No. & $\boldsymbol{\delta}_{\mathrm{H}}$ & $\delta_{\mathrm{C}}(\mathrm{DEPT})$ & No. & $\delta_{H}$ & $\delta_{\mathrm{C}}(\mathrm{DEPT})$ \\
\hline 1 & $1.27^{\mathrm{b}}, 1.55^{\mathrm{b}}, \mathrm{m}$ & $32.1\left(\mathrm{CH}_{2}\right)$ & 23 & $1.68^{\mathrm{b}}, 1.96^{\mathrm{b}}, \mathrm{m}$ & $27.9\left(\mathrm{CH}_{2}\right)$ \\
\hline 2 & $1.68^{\mathrm{b}}, 1.94^{\mathrm{b}}, \mathrm{m}$ & $30.0\left(\mathrm{CH}_{2}\right)$ & 24 & 3.91, brd,$J=10.8$ & $77.1(\mathrm{CH})$ \\
\hline 3 & $3.39, \mathrm{dd}, J=4.4,11.6$ & $89.0(\mathrm{CH})$ & 25 & - & 72.5 \\
\hline 4 & - & 42.3 & 26 & $1.43, \mathrm{~s}$ & $25.7\left(\mathrm{CH}_{3}\right)$ \\
\hline 5 & $1.93, \mathrm{~d}, J=8.8$ & $52.5(\mathrm{CH})$ & 27 & $1.41, \mathrm{~s}$ & $26.5\left(\mathrm{CH}_{3}\right)$ \\
\hline 6 & 3.78 , ddd, $J=4.4,9.6,9.6$ & $79.1(\mathrm{CH})$ & 28 & $1.78, \mathrm{~s}$ & $28.3\left(\mathrm{CH}_{3}\right)$ \\
\hline 7 & $1.82,2.25, \mathrm{~m}$ & $34.5\left(\mathrm{CH}_{2}\right)$ & 29 & $1.28, \mathrm{~s}$ & $16.6\left(\mathrm{CH}_{3}\right)$ \\
\hline 8 & $1.90, \mathrm{~m}$ & $45.8(\mathrm{CH})$ & 30 & $0.95, \mathrm{~s}$ & $19.9\left(\mathrm{CH}_{3}\right)$ \\
\hline 9 & - & 21.5 & $1^{\prime}$ & $4.77, \mathrm{~d}, J=7.6$ & $104.7(\mathrm{CH})$ \\
\hline 10 & - & 28.7 & $2^{\prime}$ & $5.52, \mathrm{dd}, J=8.0,8.0$ & $75.7(\mathrm{CH})$ \\
\hline 11 & $1.15,1,89^{\mathrm{b}}, \mathrm{m}$ & $26.3\left(\mathrm{CH}_{2}\right)$ & $3^{\prime}$ & $4.15^{\mathrm{b}}, \mathrm{m}$ & $76.3(\mathrm{CH})$ \\
\hline 12 & $1.64^{\mathrm{b}}, 2.35^{\mathrm{b}}, \mathrm{m}$ & $33.2\left(\mathrm{CH}_{2}\right)$ & $4^{\prime}$ & $4.14^{\mathrm{b}}, \mathrm{m}$ & $71.4(\mathrm{CH})$ \\
\hline 13 & (5) & 45.8 & $5^{\prime}$ & $\begin{array}{c}4.27^{\mathrm{b}}, \mathrm{m}, \mathrm{H}-5^{\prime} \mathrm{a} 3.62, \mathrm{dd} \\
J=9.6,11.6, \mathrm{H}-5^{\prime} \mathrm{b}\end{array}$ & $67.1\left(\mathrm{CH}_{2}\right)$ \\
\hline 14 & - & 46.9 & $1 "$ & $4.96, \mathrm{~d}, J=7.2$ & $105.2(\mathrm{CH})$ \\
\hline 15 & $1.45^{\mathrm{b}}, 1.66^{\mathrm{b}}, \mathrm{m}$ & $30.0\left(\mathrm{CH}_{2}\right)$ & $2^{\prime \prime}$ & $4.00, \mathrm{dd}, J=8.0,8.0$ & $75.6(\mathrm{CH})$ \\
\hline 16 & $1.33^{\mathrm{b}}, 1.54^{\mathrm{b}}, \mathrm{m}$ & $28.7\left(\mathrm{CH}_{2}\right)$ & 3" & $4.29, \mathrm{~m}$ & $79.1(\mathrm{CH})$ \\
\hline 17 & $1.51^{\mathrm{b}}, \mathrm{m}$ & $49.7(\mathrm{CH})$ & $4 "$ & $4.10, \mathrm{dd}, J=8.8,8.8$ & $72.0(\mathrm{CH})$ \\
\hline 18 & $1.38, \mathrm{~s}$ & $18.6\left(\mathrm{CH}_{3}\right)$ & $5 "$ & $3.88, \mathrm{~m}$ & $78.1(\mathrm{CH})$ \\
\hline 19 & $\begin{array}{l}0.17, \mathrm{~d}, J=4.0, \mathrm{H}-19 \mathrm{a} \\
0.53, \mathrm{~d}, J=4.0, \mathrm{H}-19 \mathrm{~b}\end{array}$ & $28.4\left(\mathrm{CH}_{2}\right)$ & $6 "$ & $\begin{aligned} 4.42, \mathrm{dd}, J & =2.4,11.2, \text { H-6"a } \\
4.29, \mathrm{dd}, J & =3.6,11.2, \mathrm{H}-6 " \mathrm{~b}\end{aligned}$ & $63.2\left(\mathrm{CH}_{2}\right)$ \\
\hline 20 & $2.39^{\mathrm{b}}, \mathrm{m}$ & $28.6(\mathrm{CH})$ & $\mathrm{COCH}_{3}$ & - & 170.0 \\
\hline 21 & $1.07, \mathrm{~d}, J=6.4$ & $18.3\left(\mathrm{CH}_{3}\right)$ & $\mathrm{COCH}_{3}$ & $2.03, \mathrm{~s}$ & $21.2\left(\mathrm{CH}_{3}\right)$ \\
\hline 22 & $1.40,1.99^{\mathrm{b}}, \mathrm{m}$ & $33.0\left(\mathrm{CH}_{2}\right)$ & & & \\
\hline
\end{tabular}

${ }^{\mathrm{a}}$ Assignments were confirmed by ${ }^{1} \mathrm{H}-{ }^{1} \mathrm{H}$ COSY, HSQC, and HMBC. ${ }^{\mathrm{b}}$ Signals are unclear due to overlapping.

Figure 2. Key ${ }^{1} \mathrm{H}-{ }^{1} \mathrm{H}$ COSY (bold dash) and HMBC (blue arrow) correlations of compound $\mathbf{1}$.

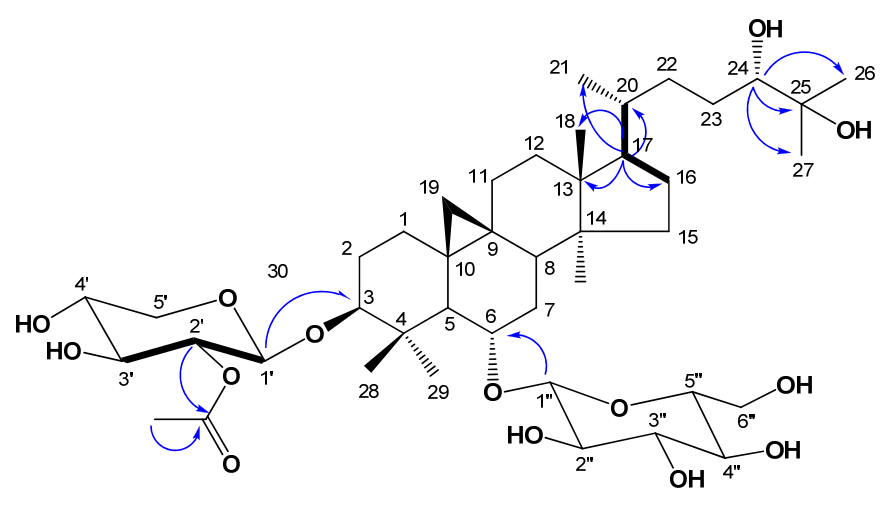

Previous studies have already reported on the anti-inflammatory effects of components obtained from A. membranaceus [9,12]. Thus, we also investigated the inhibitory effects of compounds $\mathbf{1}-\mathbf{5}$ on NO production by using the Griess reaction to measure nitrite, a soluble oxidation product of NO, in the culture medium of LPS-induced RAW 264.7 macrophages. As shown in Table 2, compounds 1-5 inhibited NO production with $\mathrm{IC}_{50}$ values in the range of 1.38 to $4.70 \mu \mathrm{M}$, respectively. Some cell 
toxicity was observed in cells treated with compounds $\mathbf{2}, \mathbf{3}$ and $\mathbf{4}$, whereas other compounds had no influence on cell viability.

Table 2. Inhibitory effects of compounds 1-5 against LPS-Induced NO production in RAW 264.7 macrophage cells.

\begin{tabular}{ccc}
\hline Compound & $\mathbf{I C}_{\mathbf{5 0}}(\boldsymbol{\mu M})^{\mathbf{a}}$ & cell viability $(\mathbf{\%})^{\mathbf{b}}$ \\
\hline 1 & $1.85 \pm 0.24$ & $93.15 \pm 6.96$ \\
2 & $1.38 \pm 0.15$ & $54.54 \pm 1.21$ \\
3 & $2.31 \pm 0.47$ & $47.56 \pm 3.40$ \\
4 & $4.70 \pm 1.77$ & $68.98 \pm 1.82$ \\
5 & $2.09 \pm 0.27$ & $94.42 \pm 4.33$ \\
Caffeic acid $^{c}$ & $0.83 \pm 1.15$ & $82.20 \pm 1.64$ \\
\hline
\end{tabular}

${ }^{\mathrm{a}} \mathrm{The} \mathrm{IC}_{50}$ value of each compound was defined as the concentration $(\mu \mathrm{M})$ that caused $50 \%$ inhibition of NO production in LPS-activated RAW 264.7 macrophage cells. Cells were pretreated for $1 \mathrm{~h}$ with compounds before stimulation with LPS $(1 \mu \mathrm{g} / \mathrm{mL})$ for $7 \mathrm{~h}$; ${ }^{\mathrm{b}}$ Cell viability indicates mean maximum inhibitory effect, at a concentration of $100 \mu \mathrm{M}$, expressed as a percentage inhibition of nitrite production induced by LPS $(1 \mu \mathrm{g} / \mathrm{mL}) \mathrm{in}$ the presence of vehicle; ${ }^{c}$ Positive control. The results are averages of three independent experiments, and the data are expressed as mean $\pm \mathrm{SD}$.

\section{Experimental}

\subsection{General}

${ }^{1} \mathrm{H}-,{ }^{13} \mathrm{C}$-, and 2D-NMR spectra were recorded on a Varian Unity Inova AS 400 FT-NMR instrument, and the chemical shifts were given in $\delta(\mathrm{ppm})$ based on the use of tetramethylsilane (TMS) as an internal standard. Optical rotations were measured on a JASCOP-1010 digital polarimeter. IR spectra were run on a Perkin Elmer Spectrum One FT-IR spectrometer. HR-FABMS spectra were obtained using a JEOL JMS-700 mass spectrometer (Tokyo, Japan). A Shimadzu gas chromatograph (GC-14B) equipped with an on-column injection system and flame ionization detector (FID) was used (Tokyo, Japan). Silica gel 60 (Merck, 230-400 mesh), LiChroprep RP-18 (Merck, 40-63 $\mu \mathrm{m}$ ), and Sephadex LH-20 (Amersham Pharmacia Biotech., Uppsala, Sweden) were used for column chromatography (CC). Pre-coated silica gel plates (Merck, Kieselgel $60 \mathrm{~F}_{254}, 0.25 \mathrm{~mm}$ ) and pre-coated $\mathrm{RP}-18 \mathrm{~F}_{254 \mathrm{~s}}$ plates (Merck) were used for analytical thin-layer chromatography analyses. Spots were visualized by spraying with $10 \%$ aqueous $\mathrm{H}_{2} \mathrm{SO}_{4}$ solution followed by heating.

\subsection{Plant Material}

The roots of $A$. membranaceus were cultivated in Jecheon, Chungbuk Province, Korea, for one year, harvested in September 2011, and identified by Dr. Jung-Hun Lee, National Institute of Horticultural and Herbal Science (NIHHS), Rural Development Administration (RDA). A voucher specimen (MPS00874) was preserved at the NIHHS, RDA. 


\subsection{Extraction and Isolation}

The roots of $A$. membranaceus $(10 \mathrm{~kg})$ were powdered and extracted three times with $36 \mathrm{~L}$ of aqueous $80 \% \mathrm{MeOH}$ at room temperature for $24 \mathrm{~h}$. After concentration in vacuo, the $\mathrm{MeOH}$ extract $(1,387 \mathrm{~g})$ was suspended in $\mathrm{H}_{2} \mathrm{O}(3 \mathrm{~L})$ and then partitioned with EtOAc $(3 \mathrm{~L} \times 3)$ followed by concentration to give the EtOAc fraction (E, $57 \mathrm{~g}$ ). Fraction E (ARE, $57 \mathrm{~g}$ ) was subjected to a silica gel $\mathrm{CC}(10 \times 21 \mathrm{~cm})$ using a gradient of $\mathrm{CH}_{2} \mathrm{Cl}_{2}-\mathrm{MeOH}-\mathrm{H}_{2} \mathrm{O}(15: 3: 1 \rightarrow 12: 3: 1 \rightarrow 9: 3: 1 \rightarrow 7: 3: 1 \rightarrow \mathrm{MeOH}$, each $2.5 \mathrm{~L}$ to yield 23 fractions (E1 to E23). Fraction E10 [2.51 g, elution volume/total volume (Ve/Vt) 0.45-0.57] was subjected to the RP-18 silica gel CC $\left[4.5 \times 12 \mathrm{~cm}, \mathrm{MeOH}-\mathrm{H}_{2} \mathrm{O}(1: 1.8,2.5 \mathrm{~L})\right]$ to give compound 2 [184 mg, Ve/Vt 0.43-0.65, (RP-18 $\left.\mathrm{F}_{254 \mathrm{~s}}\right) \mathrm{R}_{\mathrm{f}}$ 0.50, $\mathrm{MeOH}-\mathrm{H}_{2} \mathrm{O}$ (5:1)]. Subfraction E17 (400 mg, Ve/Vt 0.66-0.70) was separated by CC [RP-18 $\left.(4.5 \times 8 \mathrm{~cm}), \mathrm{MeOH}-\mathrm{H}_{2} \mathrm{O}(2.5: 1,1.5 \mathrm{~L})\right]$ to give compound 4 [25 mg, Ve/Vt 0.38-0.45, TLC (RP-18 $\left.\mathrm{F}_{254 \mathrm{~s}}\right) \mathrm{R}_{\mathrm{f}}$ 0.30, $\left.\mathrm{MeOH}-\mathrm{H}_{2} \mathrm{O}(3: 1)\right]$. Fraction E21 [140 mg, Ve/Vt 0.88-0.92] was subjected to the RP-18 CC [3.5 $\times 7.5 \mathrm{~cm}, \mathrm{MeOH}-\mathrm{H}_{2} \mathrm{O}$ (3:1) to give five subfractions (E21-1 to E21-5). Subfraction E21-3 (22 mg, Ve/Vt 0.59-0.68) was fractionated using a Sephadex LH $20 \mathrm{CC}\left[2.5 \times 50 \mathrm{~cm}, \mathrm{MeOH}-\mathrm{H}_{2} \mathrm{O}(4: 1,800 \mathrm{~L})\right]$ and yielded compound 1 [12 mg, Ve/Vt 0.66-0.85, TLC (RP-18 $\left.\mathrm{F}_{254 \mathrm{~s}}\right) \mathrm{R}_{\mathrm{f}}$ 0.40, $\mathrm{MeOH}-\mathrm{H}_{2} \mathrm{O}$ (5:1)]. Subfraction E21-6+7 (45 mg, Ve/Vt 0.59-0.68) was subjected to the RP-18 CC [2.5 $\times 7.5 \mathrm{~cm}, \mathrm{MeOH}-\mathrm{H}_{2} \mathrm{O}(3: 1)$ to give compound 5 [18 mg, Ve/Vt 0.67-0.90, TLC (RP-18 $\left.\left.\mathrm{F}_{254 \mathrm{~s}}\right) \mathrm{R}_{\mathrm{f}} 0.35, \mathrm{MeOH}-\mathrm{H}_{2} \mathrm{O}(5: 1)\right]$. Fraction E22 [140 mg, Ve/Vt 0.93-0.98] was subjected to the RP-18 CC [3.5 $\times 6 \mathrm{~cm}, \mathrm{MeOH}-\mathrm{H}_{2} \mathrm{O}(3: 1)$ to give five subfractions (E22-1 to E22-6). Subfraction E22-4 (78 mg, Ve/Vt 0.72-0.81) was fractionated using a RP-18 CC $\left[2.5 \times 5 \mathrm{~cm}, \mathrm{MeOH}-\mathrm{H}_{2} \mathrm{O}(2.5: 1,800 \mathrm{~L})\right]$ and yielded compound 3 [33 mg, Ve/Vt 0.65-0.80, TLC (RP-18 $\left.\left.\mathrm{F}_{254 \mathrm{~s}}\right) \mathrm{R}_{\mathrm{f}} 0.50, \mathrm{MeOH}-\mathrm{H}_{2} \mathrm{O}(5: 1)\right]$.

\subsection{Spectroscopic Data}

Agroastragaloside $V$ (1). Amorphous white powder; $[\alpha]_{\mathrm{D}}^{25}-18.5^{\circ}(c=0.15, \mathrm{MeOH}) ; \mathrm{IR}\left(\mathrm{CaF}_{2}\right.$ window) $\mathrm{cm}^{-1}: 3433,1724,1510,1245,1065 ; \mathrm{HR}-\mathrm{FAB} / \mathrm{MS} \mathrm{m} / \mathrm{z} 811.4777[\mathrm{M}-\mathrm{H}]^{-}$(calcd for $\left.\mathrm{C}_{43} \mathrm{H}_{71} \mathrm{O}_{14}, 811.4843\right) ;{ }^{1} \mathrm{H}-$ and ${ }^{13} \mathrm{C}-\mathrm{NMR}$ data, see Table 1.

\subsection{Acid Hydrolysis and GC Analysis}

A solution of compound $1(3 \mathrm{mg})$ in $2 \mathrm{~N} \mathrm{HCl}(2 \mathrm{ml})$ was heated at $80^{\circ} \mathrm{C}$ for $6 \mathrm{~h}$. The mixture was cooled at $0{ }^{\circ} \mathrm{C}$ and neutralization with $2 \mathrm{~N} \mathrm{NaOH}$ in $\mathrm{H}_{2} \mathrm{O}(2 \mathrm{~mL})$ and then extracted with $\mathrm{CHCl}_{3}$. The aqueous layer was concentrated under a vacuum to give a residue of the sugar fraction. The residue was dissolved in pyridine $(100 \mu \mathrm{L})$, and then $0.1 \mathrm{M}$ L-cysteine methyl ester hydrochloride $(150 \mu \mathrm{L})$ was added. After reacting at $60{ }^{\circ} \mathrm{C}$ for $90 \mathrm{~min}$, the reaction mixture was dried under a vacuum. For derivatization, $100 \mu \mathrm{L}$ of $N$-methyl- $N$-(trimethylsilyl)trifluoroacetamide (MSTFA) was added and the mixture incubated at $37{ }^{\circ} \mathrm{C}$ for $30 \mathrm{~min}$. Then, the mixture was subjected to $\mathrm{GC}$ analysis under the following conditions: capillary column, DB-5 (30 $\mathrm{m} \times 0.32 \mathrm{~mm} \times 0.25 \mu \mathrm{m})$; detector, FID; detector temperature, $280{ }^{\circ} \mathrm{C}$; injector temperature, $250{ }^{\circ} \mathrm{C}$; carrier, $\mathrm{N}_{2}$ gas $(20.4 \mathrm{~mL} / \mathrm{min})$; oven temperature, $170-250{ }^{\circ} \mathrm{C}$ with a rate of $5{ }^{\circ} \mathrm{C} / \mathrm{min}$, with one $\mu \mathrm{L}$ of each sample injected directly into the inject port (split-less mode). The peaks from the hydrolyrate of 1 were detected at 9.24 and 10.02 (D-xylose) and 
12.66 min D-glucose). The retention times for authentic samples in the same experimental conditions were detected at 9.24 and 10.02 (D-xylose, Sigma), and $12.66 \mathrm{~min}$ (D-glucose, Sigma), respectively.

\subsection{Measurement of NO Production and Cell Viability}

Assays for NO production and cell viability were carried out as previously described [17]. Briefly, RAW 264.7 macrophages were harvested and seeded in 24 -well plates $\left(3 \times 10^{5}\right.$ cells/well $)$ for the measurement of NO production. The plates were pretreated with various concentrations of samples for $1 \mathrm{~h}$ and incubated with LPS $(1 \mu \mathrm{g} / \mathrm{mL})$ for $7 \mathrm{~h}$. The amount of NO was determined by the nitrite concentration in the cultured RAW264.7 macrophage supernatants using the Griess reagent. The cell viability was evaluated by MTT reduction.

\section{Conclusions}

The new compound 3-O- $\beta$-(2'-O-acetyl)-D-xylopyranosyl-6- $O-\beta$-D-glucopyranosyl-(24S)-3 $\beta, 6 \alpha$,

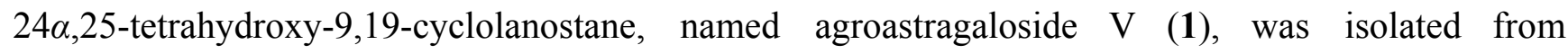
Astragalus membranaceus, together with four known cycloartane glycosides. According to previous investigations of the various Astragalus species, we have evaluated the inhibitory activities of all compounds against LPS-induced NO production in RAW264.7 macrophages. Agroastragaloside V and astragaloside IV showed significant inhibition of NO production without cytotoxicity. The results provide a potential explanation for the use of this plant as a herbal medicine in the treatment of inflammatory diseases, and they merit consideration as leads for anti-inflammatory agents.

\section{Supplementary Materials}

${ }^{1} \mathrm{H}-\mathrm{NMR},{ }^{13} \mathrm{C}-\mathrm{NMR}$, and HR-FABMS spectra of $\mathbf{1}$ are available free of charge via the internet at http://www.mdpi.com/1420-3049/18/4/3725/s1.

\section{Acknowledgements}

This work was supported by 2013 Post-Doctoral Fellowship Program of NIHH and Cooperative Research Program for Agricultural Science \& Technology Development (Project No. PJ008465), Rural Development Administration, Korea.

\section{References}

1. Evans, W.C. Trease and Evans Pharmacognosy, 15th ed.; Elsevier Science Ltd.: London, UK, 2002; p. 26.

2. Jung, B.S.; Shin, M.K. Hyang Yak Dae Sa Jeon, 3rd ed.; Young Lim Sa Publisher: Seoul, Korea, 2003; pp. 662-664.

3. Tang, W.; Eisenbrand, G. Chinese Drugs of Plant Origin: Chemistry, Phamocology and Use in Traditional and Modern Medicine; Springer-Verlag: Berlin, Germany, 1992; pp. 191-197.

4. Rios, J.L.; Waterman, P.G. A review on the pharmacology and toxicology of Astragalus. Phytother. Res. 1997, 11, 411-418. 
5. Tohda, C.; Tamura, T.; Matsuyama, S.; Komatsu, K. Promotion of axonal maturation and prevention of memory loss in mice by extracts of Astragalus mongholicus. Br. J. Pharmacol. 2006, 149, $532-541$.

6. Zhang, W.D.; Chen, H.; Zhang, C.; Liu, R.H.; Li, H.L.; Chen, H.Z. Astragaloside IV from Astragalus membranaceus shows cardioprotection during myocardial ischemia in vivo and in vitro. Planta Med. 2006, 72, 4-8.

7. Lei, H.; Wang, B.; Li, W.P.; Yang, Y.; Zhou, A.W.; Chen, M.Z. Anti-aging effect of astragalosides and its mechanism of action. Acta Pharmacol. Sin. 2003, 24, 230-234.

8. Cho, W.C.S.; Leung, K.N. In vitro and in vivo anti-tumor effects of Astragalus membranaceus. Cancer Lett. 2007, 252, 43-54.

9. Zhang, W.J.; Hufnag, P.; Binder, B.R.; Wojta, J. Anti-inflammatory activity of astragaloside IV is mediated by inhibition of NF-kappaB activation and adhesion molecule expression. Thromb. Haemost. 2003, 90, 904-914.

10. Tin, M.M.Y.; Cho, C.H.; Chan, K.; James, A.E.; Ko, J.K. Astragalus saponins induce growth inhibition and apoptosis in human colon cancer cells and tumor xenograft. Carcinogenesis 2007, $28,1347-1355$.

11. Xu, M.E.; Xiao, S.Z.; Sun, Y.H.; Ou-Yang, Y.; Zheng, X.X. Effects of astragaloside IV on pathogenesis of metabolic syndrome in vitro. Acta Pharmacol. Sin. 2006, 27, 229-236.

12. Zhang, Y.D.; Wang, Y.L.; Shen, J.P. Effects of Astragalous saponins on antiinflammation and antihypertension. Acta Pharmacol. Sin. 1984, 19, 333-337.

13. Kim, J.S.; Yean, M.H.; Lee, E.J.; Kang, S.S. Phytochemical studies on Astragalus root (1)-Saponins. Nat. Prod. Sci. 2008, 14, 37-46.

14. Hirotani, M.; Zhou, Y.; Rui, H.; Furuya, T. Cycloartane triterpene glycosides from the hairy root cultures of Astragalus membranaceus. Phytochemistry 1994, 37, 1403-1407.

15. Lee, D.Y.; Seo, K.H.; Lee, D.S.; Kim, Y.C.; Chung I.S.; Kim, G.W.; Cheoi, D.S.; Baek, N.I. 172 Bioactive 3,4-seco-triterpenoids from the fruits of Acanthopanax sessiliflorus. J. Nat. Prod. 2012, $75,1138-1144$.

16. Hirotani, M.; Zhou, Y.; Lui, H.; Furuya, T. Astragalosides from hairy root cultures of Astragalus membranaceus. Phytochemistry 1994, 36, 665-670.

17. Jung, L.H.; Lee, D.Y.; Cho, J.G.; Lee, S.M.; Kang, H.C.; Seo, W.D.; Kang, H.W.; Kim, J.Y.; Baek, N.I. A new flavonolignan from the aerial parts of Oryza sativa L. inhibits nitric oxide production in RAW 264.7 macrophage cells. J. Korean Soc. Appl. Chem. 2011, 54, 865-870.

Sample Availability: Samples of the compounds 1-5 are available from the authors.

(C) 2013 by the authors; licensee MDPI, Basel, Switzerland. This article is an open access article distributed under the terms and conditions of the Creative Commons Attribution license (http://creativecommons.org/licenses/by/3.0/). 